\title{
Evaluation of impact of Siddha Suthi (purification) processes on nut of Serankottai (Semecarpus anacardium L.)
}

\author{
Research Article
}

\section{Juliet L1* ${ }^{*}$, Sunil Kumar K N², Reena V L ${ }^{3}$, Aarthi V4, Sivakkumar S5, Karthik Raja S6, Sathiyarajeswaran S $^{7}$}

\section{Research Officer (Siddha), 2. Research Officer (Pharmacognosy), 3. Research Officer (Chemistry), 4. Research Officer (Siddha), 6. Research Associate, 7. Asst. Director,}

Siddha Central Research Institute, Central Council for Research in Siddha, Ministry of AYUSH, Govt. of India. Chennai. 5. Associate Professor, National Institute of Siddha, Ministry of AYUSH, Govt. of India, Chennai.

\begin{abstract}
Introduction: Serankottai (Semecarpus anacardium L.) is a Schedule E (1) drug and is considered for treating all kinds of Vatha diseases, venereal disease, skin disease and cancerous conditions. Suthi murai denotes the purification process before any drug is employed in medicine. This study is aimed at evaluating the impact of Siddha purification processes on macro-microscopical and physico-chemical characteristics of Serankottai so that a justification for such classical processes can be derived. Materials and Method: The raw (S1) and purified Serankottai (S2 to S6) samples were analyzed for their macroscopic, microscopic and powder microscopic analysis followed by the physicochemical parameters like loss on drying (LOD), total ash (TA), water soluble ash (WSA), acid insoluble ash (AIA), water soluble extractive (WSE), alcohol soluble extractive (ASE) and $\mathrm{pH}$ values. Results: Prismatic crystals, oil globules, sclereids, resin, fiber were observed in the microscopical studies of raw sample and these are found in the purified samples except S2 which has revealed charred cell structure. Physical nature of Serankottai has been maintained in all the purification methods except for S2. The LOD was 5.53\%, 2.90\%, 6.47\%, 5.03\%, 4.6\%, $5.05 \%$ in sampleS1, S2, S3, S4, S5 and S6 respectively. The TA values were 3.44\%, 18.90\%, 2.59\%, 2.54\% 2.7\% and $3.65 \%$ in sample S1, S2, S3, S4, S5 and S6 respectively. Significant differences in physico-chemical parameters were observed in different purification methods. Conclusion: The present study revealed that the Siddha purification processes have impact on physicochemical characters of Semecarpus anacardium. The need of the purification, as mentioned in Siddha texts is hereby justified.
\end{abstract}

Key Words: Microscopic analysis, Physicochemical characterization, Semecarpus anacardium L., Suthi, Traditional purification methods.

\section{Introduction}

Serankottai or oriental cashew nut (dried nut with peduncle of Semecarpus anacardium L. Anacardiaceae) is also called as marking nut since the black colored pigment from the nuts is used to make marks in fabrics for identification by the washer men(1).It is a moderate-sized deciduous tree found in the outer Himalayas and hotter parts of India up to 3500 $\mathrm{ft}(2)$. The important constituents of $S$. anacardium are bhilawanols, phenolic compounds $(3,4)$, bioflavonoid(5), anacardoside(6), and semecarpetin(7). S. anacardium has been proved to possess important pharmacological activities like anti-inflammatory(8-12), antiartherosclerotic(13), antioxidant $(14,15)$, CNS

* Corresponding Author:

\section{Juliet L,}

Research Officer (Siddha),

Siddha Central Research Institute,

Arumbakkam, Chennai- 600106.

Tamilnadu. India

Email Id: julisiddha@gmail.com nootropic( 16$)$, hypoglycemic(17), and anticancer $(18,19)$.

The Drugs and Cosmetics Act, 1940 categorized some of the Siddha plant drugs under Schedule E (1) classifications, so that these drugs are toxic and advised to take with more precautions. It is recommended to assure these drugs undergo purification process before they are used in medicinal preparation. Serankottai, a Siddha drug is one among the Schedule E (1) drugs (20).

Siddha system emphasizes the Suthi (purification) process of a drug before it is incorporated in any medicinal preparations. The purification process is to remove toxic content before it is used in medicine to counteract the toxic symptoms and to enhance its efficacy is termed as Suthimurai (purification process) in Siddha system of medicine. Purification processes are employed for all poisonous drugs from herbs, minerals, metals and animal origins and it is recommended for all drugs to remove their kutram (impurities or unwanted toxic content). The purification is done by various pharmaceutical procedures like boiling, frying, washing, triturating with various plant juices; pudam (calcination) method; 
grinding with specific organic or inorganic materials; soaking in specific media etc to minimize the toxicity of the substances and to strengthen the efficacy of the drug.

Purification is done to reduce the toxicity of the drug by potentiating the conversion of high toxic components to less toxic molecules or chemical structure. Siddha classical text have emphasized various Suthi muraigal (purification methods) to overcome the unwanted effects from various poisonous and nonpoisonous drugs, involving different media specific to substances such as pasum chaanam (cow dung), komium (cow's urine), erumai chaanam (buffalo dung), arisi kaadi (rice vinegar), herbal kasayams (decoctions), herbal juices like Aloe vera juice, fruit juices like lemon juice,etc.

S. anacardium nuts is also known as Senkottai, Vallathy, Vallathaki, Nandhiviththu and Erimugi in Tamil. It is bitter in taste, hot in nature and is indicated for many chronic diseases like perunoi (leprosy), ilaippunoi (tuberculosis), soolai (pricking pain), venpadai (leucoderma), moolam (piles), and gunmam (gastritis)(21). Medicines prepared from Serankottai in Siddha are Nandhimai, Serankottai legium, Serankottai nei (22), Seenavallathy urundai, Gandhavallathy, Sindhuvallathy, Amirdha Gandhi kukil vallathy, Vallathy churanam, etc (23).

In the present study, different forms of $S$. anacardium nuts (unpurified and purified nuts following different Siddha methods of purification Table 1) were analyzed to evaluate the macromicroscopic and physicochemical characters.

\section{Table 1. Siddha methods of purification of Serankottai}

\begin{tabular}{|c|c|c|}
\hline Process & Method with classical reference & Sample \\
\hline 1 & $\begin{array}{l}\text { The peduncles removed SA nuts were } \\
\text { placed in the midst of limestone, the } \\
\text { palm toddy were sprinkled on it. This } \\
\text { process was repeated for } 6 \text { times and } \\
\text { the SA nuts were washed and dried } \\
(21) \text {. }\end{array}$ & S2 \\
\hline 2 & $\begin{array}{l}\text { SA nuts were kept in a white cotton } \\
\text { cloth and tied at the top to make } \\
\text { kizhi. This kizhi was kept in the mud } \\
\text { pot and boiled in decoction of } \\
\text { tamarind leaves, decoction of Butea } \\
\text { monosperma, filtrate of cow dung } \\
\text { mixed with water and Aloe vera juice } \\
\text { separately (21). }\end{array}$ & S3 \\
\hline 3 & $\begin{array}{l}\text { SA nuts were taken in a mud pot } \\
\text { without removing the cotyledons. } \\
\text { Palm toddy and curd prepared from } \\
\text { the milk of red colour cow were } \\
\text { mixed and SA nuts were immersed in } \\
\text { the mixture for } 9 \text { days continuously } \\
\text { (21). }\end{array}$ & S4 \\
\hline 4 & $\begin{array}{l}\text { The cotyledons removed SA nuts } \\
\text { were soaked in the kazhuneer } \\
\text { (kaikuthalarisi soaked water) for } 3 \mathrm{~h} \text {. } \\
\text { Then the SA nuts were soaked in } \\
\text { buffalo milk for } 3 \mathrm{~h} \text { and were used } \\
\text { for analysis after drying (24). }\end{array}$ & S5 \\
\hline
\end{tabular}

5 The cotyledons removed SA nuts were boiled in the filtrate of cow dung mixed in water for $3 \mathrm{~h}$. The process was done for 7 times as said above. The above processed SA nuts were made into Kizhi and kept in puliilai kudineer (Tamarindus indica leaf decoction) and boiled for $3 \mathrm{~h}$. The above processed SA nuts were immersed in cow's milk and kept for one day. The next day it was boiled for $3 \mathrm{~h}$. Then they were processed with Aloe vera juice and tender coconut in the same manner. The above processed SA nuts were immersed in Aloe vera juice and kept for one day. Then it was boiled for 3 $\mathrm{h}(25)$.

\section{Materials and methods}

The nuts of $S$. anacardium with peduncles were purchased from raw drug store K. Ramasamy Chetty country raw drug store, Paris corner, Chennai and authenticated at the Department of Pharmacognosy, SCRI, Chennai. The raw sample of Serankottai (S1) was analyzed followed by samples purified by five processes (S2, S3, S4, S5, and S6) mentioned in classical Siddha texts (Table 1). The samples were analyzed for macro-microscopical and physiochemical parameters and the results were discussed.

\section{Macro-microscopic examinations}

The nuts of Semecarpus anacardium of six samples were subjected to macroscopic, microscopic and powder microscopic characters following standard procedures $(26,27)$.

\section{Physico-chemical Analysis}

Physicochemical studies of the unpurified SA nut sample S1and purified SA nut samples S2 to S6 were done according to the PLIM guidelines $(26,27)$.

\section{Organoleptic characters}

The organoleptic characters of the sample drug were evaluated in self. The samples S1-S6 were taken and the color, texture, smells, taste were tested $(26,27)$.

\section{Loss on Drying}

Accurately weighed $4 \mathrm{~g}$ of the powdered drug was dried in the oven at $105^{\circ} \mathrm{C}$ to constant weight and percentage moisture content was calculated.

\section{Determination of Ash Values Total Ash}

Four grams of the test drug was accurately weighed and incinerated in silica crucible at $600^{\circ} \mathrm{C}$ until free from carbon. It was then cooled and weighed. The $\% \mathrm{w} / \mathrm{w}$ of ash with reference to the air dried powder was calculated.

\section{Water Soluble Ash}

The total ash was obtained as per the above mentioned method. The ash was boiled for $5 \mathrm{~min}$ with 
$25 \mathrm{ml}$ water. The insoluble ashes were collected using ashless filter paper and washed with hot water and then transferred to the silica crucible, ignited the ashless filter paper for $15 \mathrm{~min}$ at $600^{\circ} \mathrm{C}$. The silica crucible and residue were weighed until constant weight is attained. The weight of the watersoluble ash was determined by subtracting the weight of insoluble ash from the weight of total ash.

\section{Acid insoluble Ash}

The ash obtained from the above was boiled for 5 min with $25 \mathrm{ml} 10 \% \mathrm{HCl}$.The insoluble ashes were filtered and collected in a crucible. Washed with hot water and ignited to constant weight. Percentage of acid insoluble ash was calculated.

\section{Determination of Extractive Value Alcohol Soluble Extractive}

Four grams of test drug were weighed and macerated with $100 \mathrm{ml}$ of absolute alcohol in a closed conical flask. The solution was shaken continuously for $6 \mathrm{~h}$ and allowed to stand and soak for $18 \mathrm{~h}$. The solution was filtered and the filtrate was evaporated in a petri dish at $105^{\circ} \mathrm{C}$, then cooled and weighed. Percentage of alcohol soluble extractive value was calculated.

\section{Water soluble Extractive}

Four grams of test drug powder was weighed and macerated with $100 \mathrm{ml}$ of water, in a closed conical flask. The resulting solution was shaken continuously for $18 \mathrm{~h}$ and allowed to stand and soak for $18 \mathrm{~h}$ and then filtered. $25 \mathrm{ml}$ of the filtrate was evaporated to dryness in an evaporating dish, dried at $105^{\circ} \mathrm{C}$ and weighed. Percentage of water soluble extractive value was calculated.

\section{pH}

$10 \%$ solution of SA nuts was prepared in distilled water $(\mathrm{w} / \mathrm{v})$ and $\mathrm{pH}$ was determined by using digital $\mathrm{pH}$ meter.

\section{Results}

\section{Macroscopy of nuts}

The dried fruits of Semecarpus anacardium are laterally flattened, drupaceous, dark brown, obliquely ovoidnut, surface smooth and sometimes shining with residual receptacle. The fruits of the six samples differed slightly in their dimensions. The $\mathrm{S} 4$ sample was biggest among the six samples measuring 2.8 to $3.5 \mathrm{~cm}$ in length and 2 to $2.5 \mathrm{~cm}$ in breadth. The dimensions and the surface morphology of the individual samples are given in Figure 1 and Table 2.

Figure 1.External morphology of Semecarpus anacardium nut after different purification processes

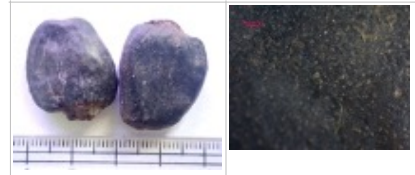

S1

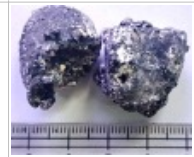

S2

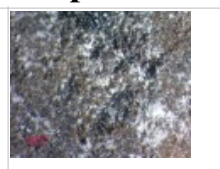

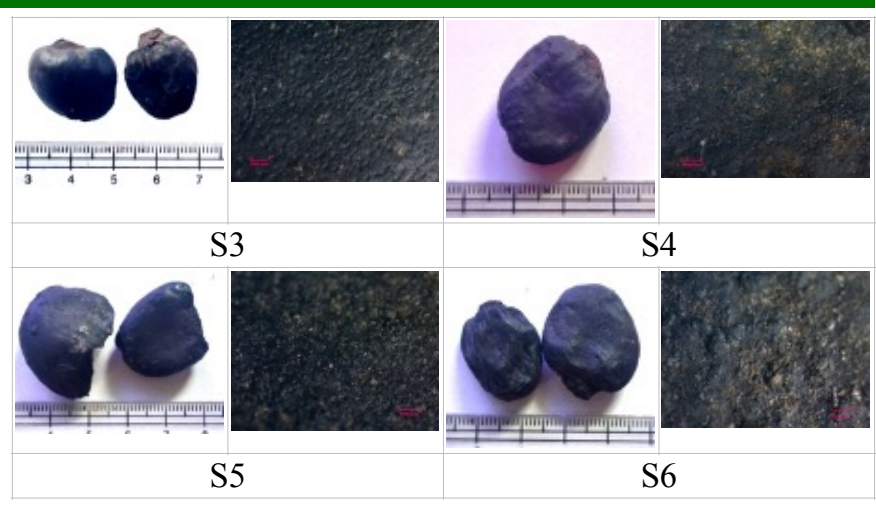

Table 2. External Morphology of the Semecarpus anacardium nut samples

\begin{tabular}{|l|l|l|l|l|}
\hline Sample & $\begin{array}{c}\text { Length } \\
\text { (cm) }\end{array}$ & $\begin{array}{c}\text { Breadth } \\
\text { (cm) }\end{array}$ & \multicolumn{1}{|c|}{ Colour } & \multicolumn{1}{|c|}{ Texture } \\
\hline $\mathbf{S 1}$ & 1.5 to 2 & 1.3 to 1.5 & $\begin{array}{l}\text { Greyish } \\
\text { black }\end{array}$ & $\begin{array}{l}\text { Nearly even } \\
\text { with minute } \\
\text { depressions }\end{array}$ \\
\hline $\mathbf{S 2}$ & 2 to 2.2 & 1.5 to 1.7 & $\begin{array}{l}\text { Black with } \\
\text { white } \\
\text { patches }\end{array}$ & $\begin{array}{l}\text { Rough } \\
\text { surface with } \\
\text { crevices and } \\
\text { white } \\
\text { deposits }\end{array}$ \\
\hline $\mathbf{S 3}$ & 2.3 to 2.5 & 1 to 1.5 & Black & $\begin{array}{l}\text { Uneven with } \\
\text { small } \\
\text { protrusions } \\
\text { Smooth with } \\
\text { golden } \\
\text { patches }\end{array}$ \\
\hline $\mathbf{S 4}$ & 2.1 to 2.4 & 1.8 to 1.2 & Black & $\begin{array}{l}\text { Uneven with } \\
\text { small } \\
\text { protrusions }\end{array}$ \\
\hline $\mathbf{S 5}$ & 2 to 3.5 & 1.8 to 2.5 & $\begin{array}{l}\text { Greyish } \\
\text { black }\end{array}$ \\
\hline S6 & 2 to 2.8 & 1.5 to 2.2 & $\begin{array}{l}\text { Shining } \\
\text { black }\end{array}$ & Nearly even \\
\hline
\end{tabular}

It was observed that the surface morphology of the nuts varied with the samples. Sample S6 had a nearly smooth surface followed by S1. Sample S2 had a charredlike surface may be due to the purification by treatment with lime. Samples S3 and S5 had nearly similar type of surfaces. In the sample S4 minute golden patches were visible which was absent in all the other five samples.

\section{Microscopy}

Microscopically the raw nut sample showed the fruit wall differentiated into epicarp, mesocarp and endocarp. Epicarp shows epidermis consisting of single layer of elongated lignified cells arranged radially covered above by a thin layer of prominent cuticle. In some places some of epidermal cells rupture along with the cuticle and resin drops is exuded out. Mesocarp consists of broad zone of parenchymatous cells arranged in numerous $(>25)$ layers. The cells of the upper layers are bigger in size while the lower layer cells are smaller. Rosette crystals are seen randomly scattered. Fibro vascular bundles are also seen scattered. Some of the mesocarp cells get dissolved to form the lysogenic cavities filled with resin. Endocarp is differentiated into outer shorter and thinner layers of cells followed by prismatic layer of radially arranged very elongated thick walled cells. Below the endocarp 
Juliet L et.al., Evaluation of impact of Siddha Suthi (purification) processes on nut of Serankottai (Semecarpus anacardium L.)

cotyledons are seen containing numerous fixed oil cells and oil globules (Figure 2).

Figure 2. Microscopy of Semecarpus anacardium nut sample - S1

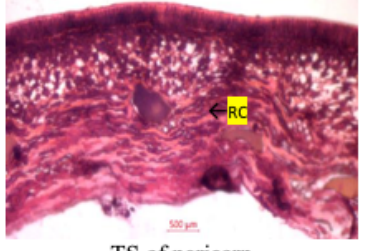

TS of pericarp

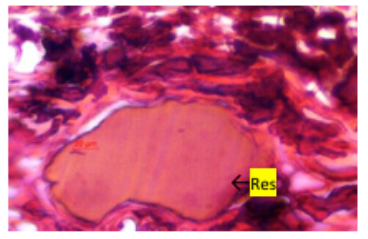

Resin cavity in mesocarp
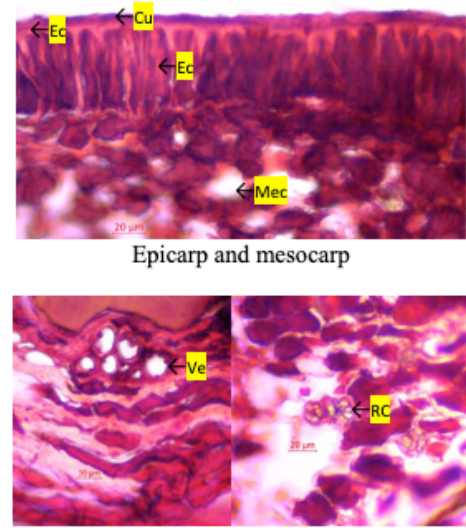

Vascular bundle and Rosette crystals

$\mathrm{Cu}$ - Cuticle; Ec - Epicarp; Mec- Mesocarp; Res Resin canal; RC- Rosette crystal; Ve - Vessel

Microscopically S2 showed charring of the cell wall, the contents of the cells such as resin content is not observed clearly (Figure 3 ).

Figure 3. Microscopy of Semecarpus anacardium nut sample - S2

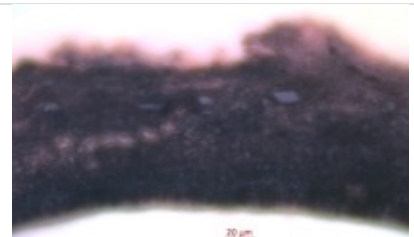

TS of pericarp shows no resin in cavities

Microscopically S3 showed characters similar to that of raw nuts (Figure 4).

Figure 4. Microscopy of Semecarpus anacardium nut sample - S3

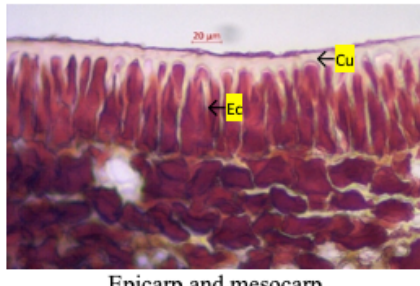

Epicarp and mesocarp

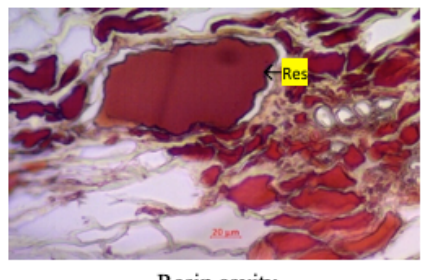

Resin cavity

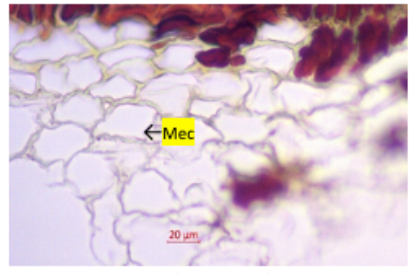

Mesocarp parenchyma without contents

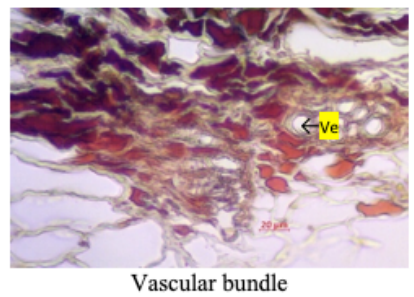

$\mathrm{Cu}$ - Cuticle; Ec - Epicarp; Mec- Mesocarp; Res - Resin canal; Ve - Vessel

Microscopically S4 showed characters similar to that of raw nuts (Figure 5).
Figure 5. Microscopy of Semecarpus anacardiumnut sample - S4
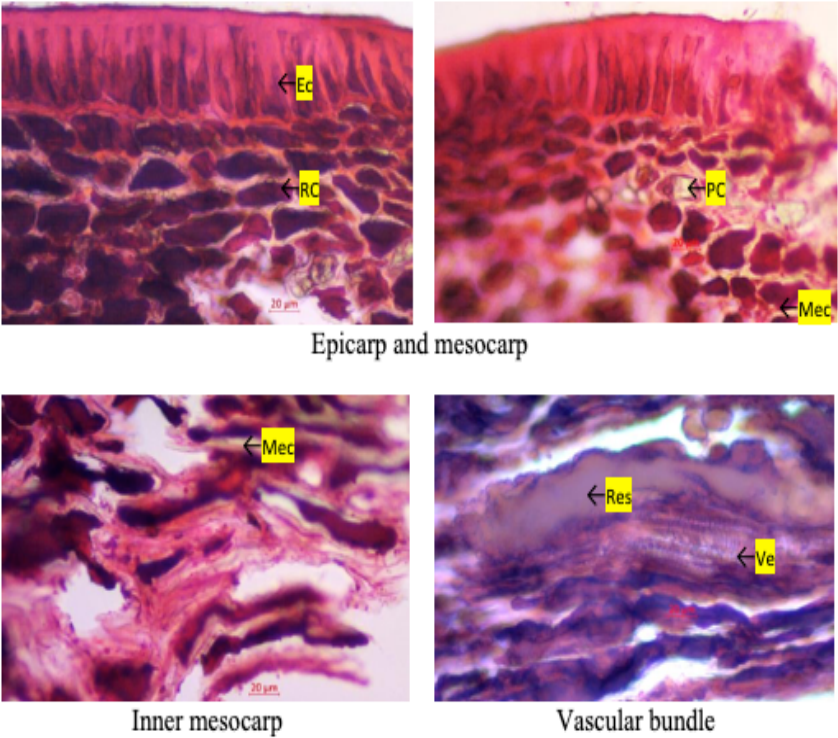

Vascular bundle

$\mathrm{Cu}$ - Cuticle; Ec - Epicarp; MecMesocarp; Res -

Resin canal; RC- Rosette crystal;Ve- Vessel

Microscopically S5 showed characters similar to that of raw nuts (Figure 6).

Figure 6. Microscopy of Semecarpus anacardiumnut sample - S5
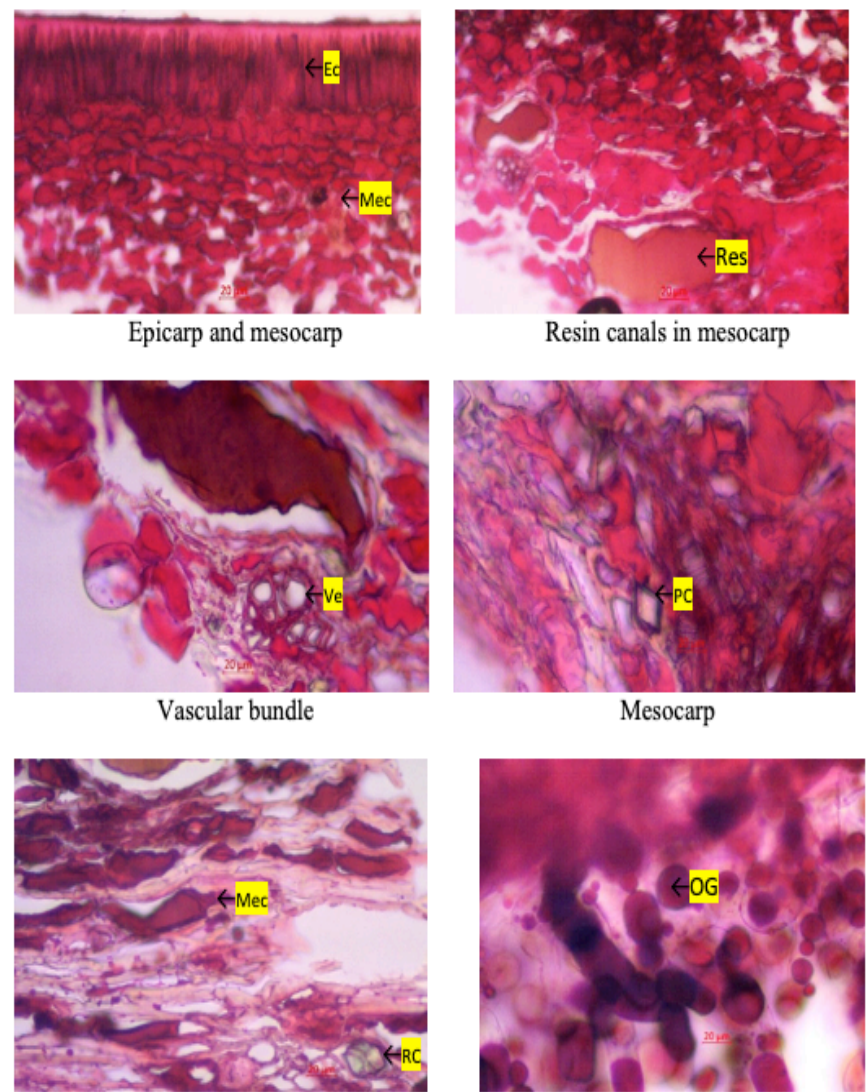

$\mathrm{Cu}$ - Cuticle; Ec - Epicarp; Mec- Mesocarp; OG - Oil globule; PC- Prismatic crystal; RC- Rosette crystal; VeVessel.

Microscopically S6 showed characters similar to that of raw nuts (Figure 7). 
Figure 7. Microscopy of Semecarpus anacardiumnut sample - S6
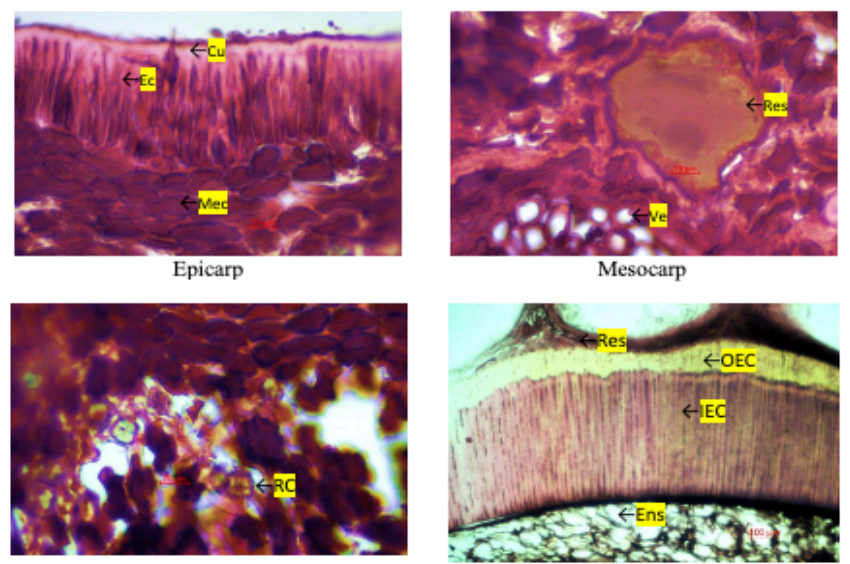

Rosette crystals
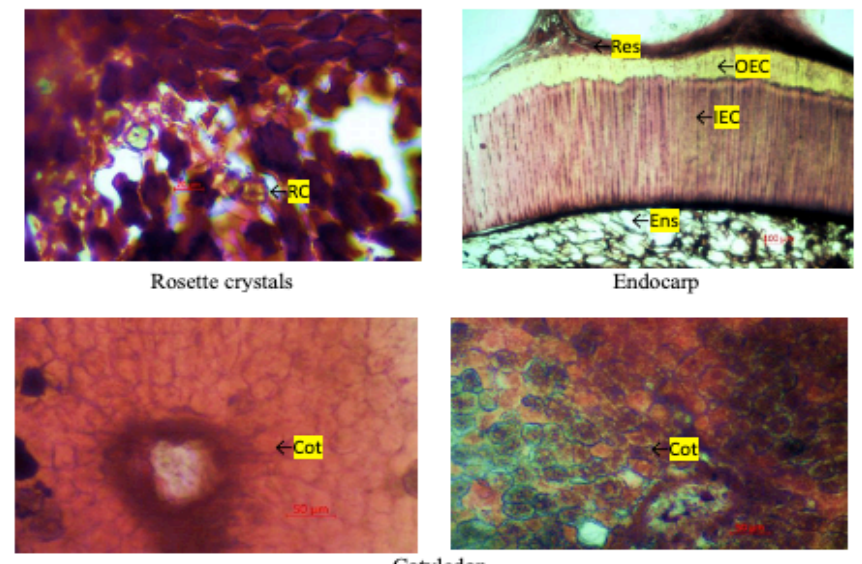

Cot - Cotyledon; $\mathrm{Cu}$ - Cuticle; Ec - Epicarp; Ens Endosperm; IEC - Inner endocarp; Lys - Lysogenic cavity; Mec- Mesocarp; OEC - Outer endocarp; RC -

Rosette crystals; Res - Resin canal; Ve- Vessel.

The effect of the purifications processes performed on the drug was not evident as any change in the microscopical structures or content of the nut was not observed.

Powder of raw nuts (S1) showed characters as shown in the Figure9.

\section{Figure 9. Powder microscopy of sample S1}
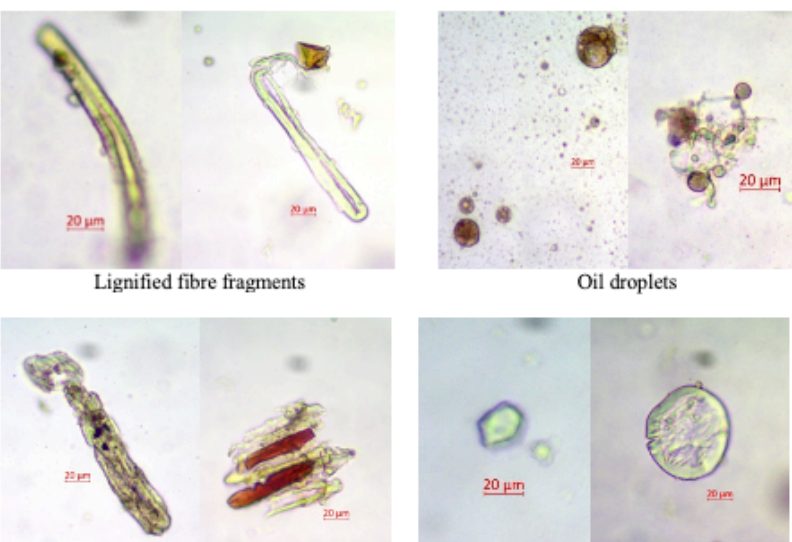

Sclereids of endocarp and resin cells
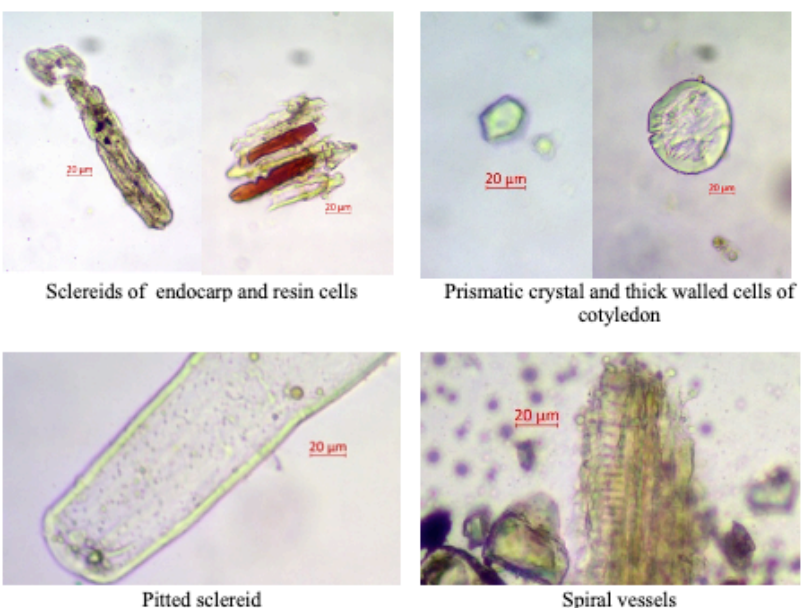

Powder of S2 showed characters as shown in the Figure 10.
Figure 10. Powder microscopy of sample S2
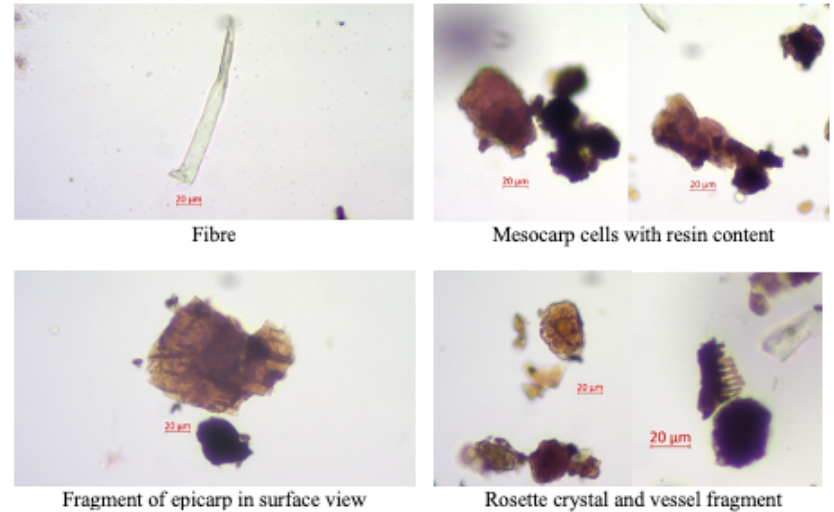

Powder of S3 showed characters as shown in the Figure 11.

Figure 11. Powder microscopy of sample S3
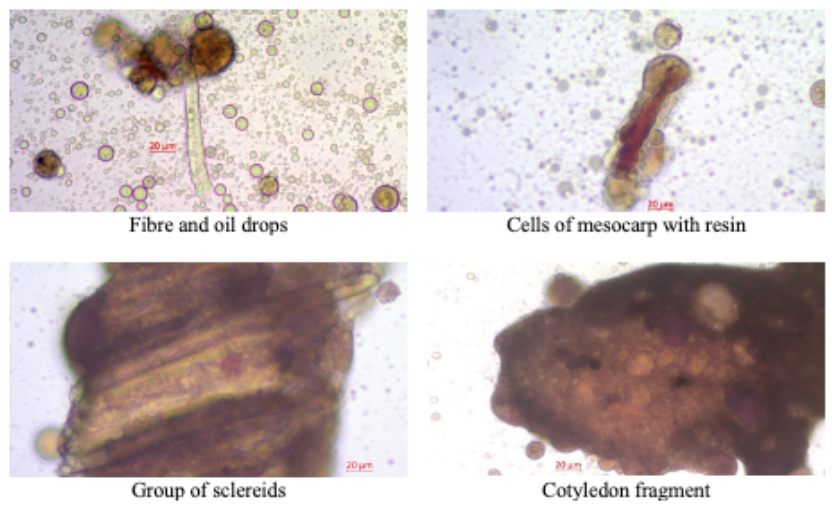

Powder of S4 showed characters as shown in the Figure 12.

\section{Figure 12. Powder microscopy of sample S4}

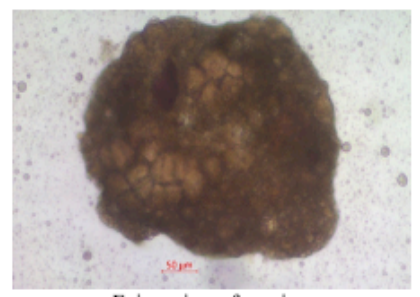

Epicarp in surface view
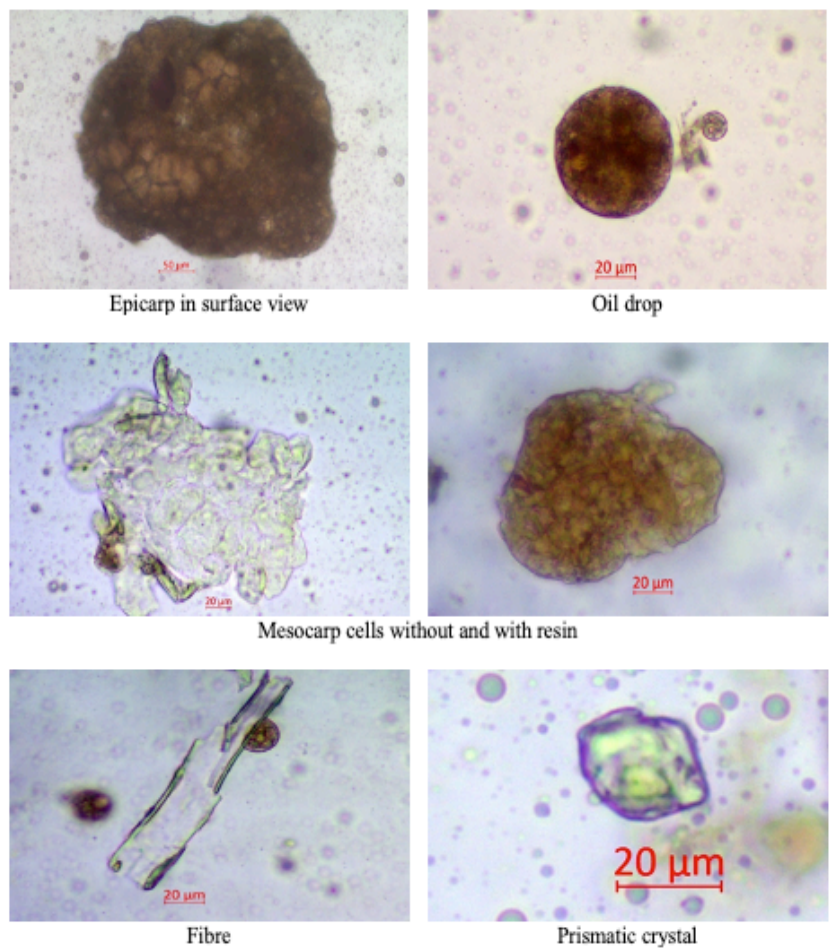

Powder of S5 showed characters as shown in the Figure 13. 


\section{Figure 13. Powder microscopy of sample S5}
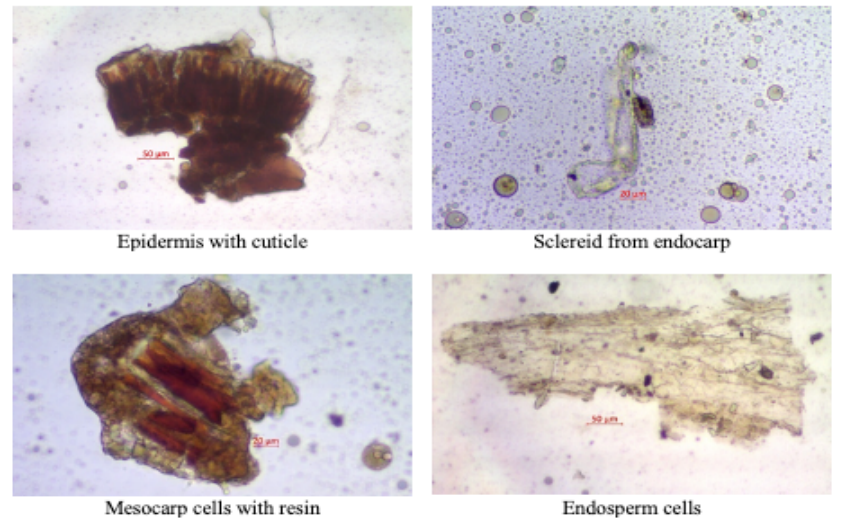

Powder of S6 showed characters as shown in the Figure 14.

Figure 14. Powder microscopy of sample S6

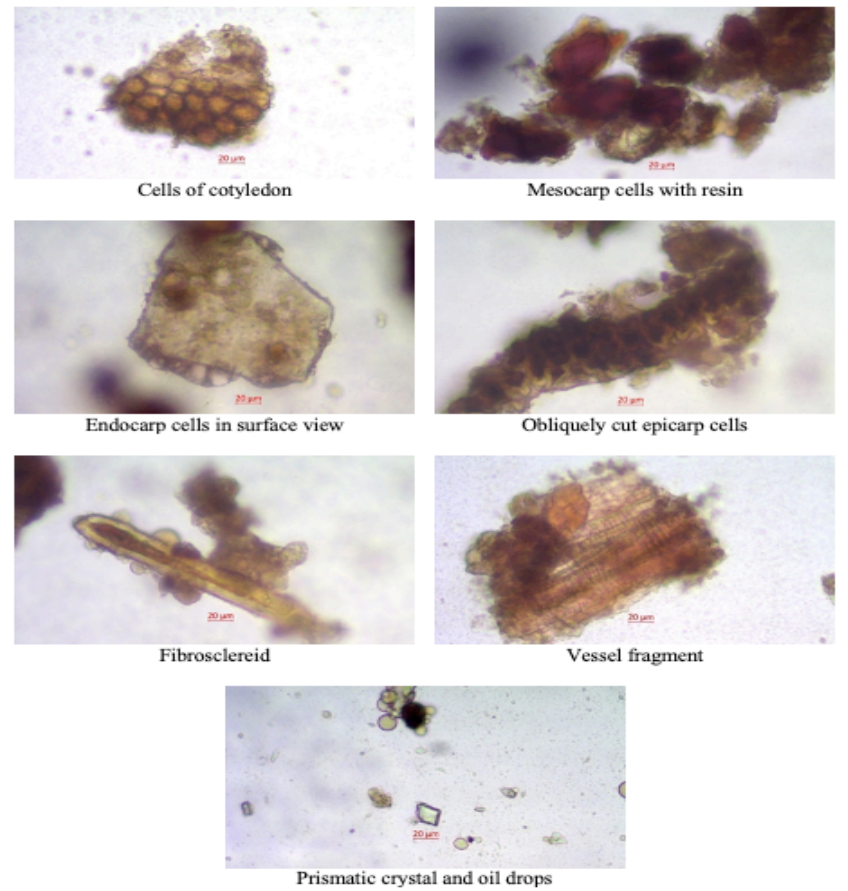

Physico-chemical characterization showed differencesin values for loss on drying, total ash, water soluble ash, acid insoluble ash, water soluble extractive, alcohol soluble extractive and $\mathrm{pH}$ between samples $\mathrm{S} 1$ to S6 (Table3.)Sample S2 showed vast difference in all the parameters tested when compared to other samples.

\section{Table 3: Comparison of Physicochemical Parameters} in $\mathrm{S1}$ to $\mathrm{S6}$

\begin{tabular}{|l|l|l|l|l|l|l|}
\hline Parameters & S1 & S2 & S3 & S4 & S5 & S6 \\
\hline LOD & $5.53 \%$ & $2.90 \%$ & $6.47 \%$ & $5.03 \%$ & $4.6 \%$ & $5.05 \%$ \\
\hline Total Ash & $3.44 \%$ & $18.90 \%$ & $2.59 \%$ & $2.54 \%$ & $2.7 \%$ & $3.65 \%$ \\
\hline $\begin{array}{l}\text { Water soluble } \\
\text { ash }\end{array}$ & $1.30 \%$ & $0.65 \%$ & $0.70 \%$ & $1.30 \%$ & $1.00 \%$ & $0.80 \%$ \\
\hline $\begin{array}{l}\text { Acid insoluble } \\
\text { ash }\end{array}$ & $1.94 \%$ & $9.05 \%$ & $1.34 \%$ & $0.05 \%$ & $0.55 \%$ & $2.50 \%$ \\
\hline $\begin{array}{l}\text { Water soluble } \\
\text { extractive }\end{array}$ & $11 \%$ & $12.75 \%$ & $13.05 \%$ & $7.75 \%$ & $11 \%$ & $12.5 \%$ \\
\hline $\begin{array}{l}\text { Alcohol soluble } \\
\text { extractive }\end{array}$ & $27 \%$ & $12.75 \%$ & $23.13 \%$ & $31 \%$ & $27 \%$ & $40 \%$ \\
\hline \begin{tabular}{l} 
Ph \\
\hline
\end{tabular} & 7.34 & 8.43 & 7.01 & 6.5 & 7.15 & 6.63 \\
\hline
\end{tabular}

\section{Discussion}

Macroscopic, microscopic and powder microscopic features of six samples of Semecarpus anacardium nuts purified by different Siddha methods have been studied. Slight difference in the texture of fruit wall was found among samples; the texture in case of sample S2 was totally different showing charred appearance as it is treated with limestone. Microscopically no remarkable differences were observed except sample S2; cell structure and content of sample S2 have been altered remarkably by the limestone treatment. The results of macro-microscopic observations matched with that reported earlier in the literature (28). There are about 5 types of calcium oxalate crystals present in plants in the following forms such as prisms, styloids, raphides, druses and crystal sand $(29,30)$. Researchers reported that these crystals are not toxic component but they act as defense mechanism and protect the plant parts from foraging animals $(31,32)$. The prismatic crystals and rosette crystals are found in these samples. The crystals are used for identification a raw herb under microscope (33).The quality and purity of the drug has been studied by the pharmacognosy characters of anatomy and cell inclusions in all the 6 samples (34) which has been proved by the reduction of anacardic acid in Semecarpus anacardium nuts after the above mentioned purification processes (35).

The Loss on drying which reveals the moisture content of all the samples were within the limits (5 to $8 \%$ ) as per WHO (27). Low moisture content in the samples indicates a better stability and shelflife. An herbal sample free of moisture and can be stored for a long time without the microbial contamination. The acid insoluble ash in all samples except $\mathrm{S} 2$ represents lower inorganic matter and less contamination, also it plays important role in absorption in the gut (36). Higher limit of acid insoluble ash in sample S2 maybe due to the presence of lime stone involved in the purification process. High extractive value indicates higher content of secondary metabolites; the test is indication of absence of exhausted material, adulteration and substitution (37). High alcohol soluble extractive compared to water soluble extractive shows that Serankottai is less soluble in water because of its oily nature.But other ingredients which are used in formulations may change its solubility. Extractive values usually represent presence of many phytoconstituents which can be identified by HPTLC.The alcohol soluble extractive values indicated the presence of polar constituents like phenols, alkaloids, steroids, flavonoids while the water soluble fraction might be due to presence of glycosides. Water soluble extractive values observed shows that the glycoside presence as evidenced from phytochemical quantification analysis. Further chemical studies may give some clue on possible effects of treatments with different media.

\section{Conclusion}

According to Siddhars, even a poisonous drug can be converted to a life saving medicine. SA nuts after 
suthi process do not cause any allergy or untoward effect when it is consumed as prepared medicine (38).A preliminary study to evaluate the changes that occurred in the Semicarpus anacardium nuts has been documented in the samples before and after the purification process. This study may give an idea on the physicochemical and pharmacognostic parameters and their difference in raw and purified samples. Further studies can be done to document the possible chemical changes during Suthi process.

\section{References}

1. Fok, JieShen et al. Marking nut anaphylaxis. Asia Pacific allergy. 2016; 6(3): 192-4. doi:10.5415/ apallergy.2016.6.3.192.

2. Kirtikar KR, Basu BD. Indian medicinal plants. Vol. 3. Dehradun; International Booksellers and Publishers; 1975.667p.

3. Mathur HN, Agarwal JS. Phenolic modified resin of oil varnishes. J Sci Indian Res. 1953; 12 ;411. [Google Scholar]

4. Rao NS, Row LR, Brown RT. Phenolic constituents of Semecarpus anacardium. Phytochemistry. 1973; 12; 671-81. [Google Scholar]

5. Ishatulla K, Ansari WH, Rahman W, Okigawa M, Kawanon N. Bioflavanoids from Semecarpus anacardium linn. Indian J Chem. 1977; 15; 617 22. [Google Scholar]

6. Majumdar SH, Kulkarni SB, Chakraborthy GS. Medicinal potientials of Semecarpus anacardium nut: A review. J Herb Med Toxicol. 2008; 2; 9-13. [Google Scholar]

7. Murthy SS. Semicarpetin: A biflavonoid from Semecarpus anacardium. Phytochemistry. 1988; 27; 30202. [Google Scholar]

8. Ramprasath VR, Shanthi P, Sachdanandam P. Immunomodulatory and antiinflammatory effects of Semecarpus anacardium Linn. Nut milk extract in experimental inflammatory conditions. Biol Pharm Bull. 2006; 29; 693-700. [PubMed] [Google Scholar]

9. Selvam C, Jachak SM. A cyclooxygenase (COX) inhibitory biflavonoid from the seeds of Semecarpus anacardium. J Ethnopharmacol. 2004 Dec; 95(2-3); 209-12. doi: 10.1016/ j.jep.2004.07.026. PMID: 15507338 .

10. Bhitre MJ, Patil S, Kataria M, Anwikar S, Kadri H. Antiinflammatory activity of the fruits of Semecarpus anacardium Linn. Asian J Chem. 2008; 20; 2047-50. [Google Scholar]

11. Satyavati GV, Prasad DN, Das PK, Singh HD. Anti inflammatory activity of Semecarpus anacardium Linn. A preliminary study. Indian J Physiol Pharmacol. $1969 ; 13 ; 37-$ 45. [PubMed] [Google Scholar]

12. Singh D, Aggarwal A, Mathias A, Naik S. Immuno modulatory activity of Semecarpus anacardium extract in mononuclear cells of normal individuals and rheumatoid arthritis patients. J
Ethnopharmacol. $2006 ; 108 ; 398-$ 406. [PubMed] [Google Scholar]

13. Sharma A, Mathur R, Dixit VP. Hypocholesterolemic activity of nut shell extract of Semecarpus anacardium (Bhilawa) in cholesterol fed rabbits. Indian J Exp Biol. 1995; 33; 444 8. [PubMed] [Google Scholar]

14. Verma N, Vinayak M. Bioscience Reports Immediate Publication; 2008. p. BSR20080035. [PubMed] [Google Scholar]

15. Sahoo AK, Narayanana N, Sahanaa S, Rajanb SS, Mukherjee PK. In vitro antioxidant potential of Semecarpus Anacardium L. Pharmacology online. 2008; 3; 327-35. [Google Scholar]

16. Farooq SM, Alla TR, Rao NV, Prasad K, Shalam K, Satyanarayana S. A study on CNS effect of nut milk extract of Semicarpus anacardium. Pharmacology online. 2007; 1; 49-63. [Google Scholar]

17. Arul B, Kothai R, Christina AJ. Hypoglycemic and antihyperglycemic effect of Semecarpus anacardium Linn in normal and streptozotocininduced diabetic rats. Methods Find Exp Clin Pharmacol. 2004; 26; 759-62. [PubMed] [Google Scholar]

18. Veena K, Shanthi P, Sachdanandam P. The biochemical alterations following administration of Kalpaamruthaa and Semecarpus anacardium in mammary carcinoma. Chem Biol Interact. 2006; 161; 69-78. [PubMed] [Google Scholar]

19. Mathivadhani P, Shanthi P, Sachdanandam P. Apoptotic effect of Semecarpus anacardium nut extract on T47D breast cancer cell line. Cell Biol Int. 2007; 31; 1198-206. [PubMed] [Google Scholar]

20. Drugs and Cosmetics act 1940 with Drugs and Cosmetics Rules, Ministry of Health and Family Welfare (Department of Health), Government of India; 2003. 266p.

21. Murugesa Mudhaliyar K S. Gunapadam-mooligai vaguppu. 2nd edition; Chennai; Directorate of Indian Medicine and Homeopathy; 2008.

22. Kuppusamy KN, Uththamarayan KS. Siddha vaithyathiratu; Department of Indian medicine and Homeopathy; 2006.

23. Veluchamy K. Agathiyar vallathy 600. 2 nd edition. New Delhi; Central Council for Research in Ayurvedha and Siddha; 2005.

24. Kannusamypillai C. Sikitcha rathna deepam enum vaithya nool. Chennai; Rathnanayakkar and sons; 2007.

25. Mohamed Abdulla shakibu. Anuboga vaithiya navaneetham Part-8. Chennai; Thaamarai noolagam; 1995.

26. Lohar DR. Protocol for Testing of Ayurveda, Siddha \&Unani medicines,Govt.of India, Dept.of AYUSH, Ministry of Health and Family Welfare, Pharmacopoeial Laboratory for Indian Medicines, Ghaziabad.

27. Anonymous. Quality Control Methods for Medicinal Plant Materials. Geneva: World Health Organization; 1998. 
28. Ilanchezhian R, Joseph C Roshy, RN Acharya, CR Harisha, VJShukla. Pharmacognostical and Physicochemical Analysis of Bhallataka (Semecarpusanacardium Linn.) - Fruit. Pharmacognosy Journal. 2011; 3(20); 9-16.

29. Cutter, E.G. Plant anatomy. Part I. Cells and tissues. New Delhi; Oxford and IBH; 1978.

30. Metcalfe, C.R, and L. Chalk. Anatomy of the dicotyledons. Oxford; Clarendon Press; 1950.

31. Kingsbury J.M. Poisonous plants of the United states and Canada. Prentice Hall; Englewood diffs. NJ; 1964.

32. Onyeike, E. N. and Osuji, J. O. (eds.). Cytogenetics techniques. In: Research Techniques in Biological and Chemical Sciences. Nigeria; Springfield Publishers Ltd.; 2003. 70-83p.

33. Anitha and Sandhiya. Occurance of Calcium oxalate crystals in the leaves of medicinal

34. Plants. International Journal of Pharmacognosy. 2014; 1(6); 389-393.

35. Sumitra S., Vijay N, Surendra K.S. Pharmacognostic Studies on the Leaves of Prosopis cineraria (L) Druce. Growing in South Haryana India. Journal of Pharmacognosy and Phytochemistry. 2013;2(1);320.
36. Lawrence J, Viswan Lilly $\mathrm{R}$, Velmurugan A, Sundhara Moorthy KR, Sudarsanam SR, Parameswaran S, Kadarkarai K. Quantification of anacardic acid, the toxic component in raw and purified samples of Semecarpus anacardium L. by Siddha purification processes. J Complement Integr Med. 2021 May 19. Epub ahead of print.

37. Ajazuddin, and Shailendra Saraf. Evaluation of physicochemical and phytochemical

38. properties of Safoof-E-Sana, a Unani polyherbal formulation. Pharmacognosyresearch 2010; 2(5); 318-22. doi:10.4103/0974-8490.72332.

39. Kumar Sarvesh, Maurya Santhosh Kumar, Seth Ankit, Singh Anil Kumar, Quality Control Standardization of the Bark of Moringa oleifera LAM. International Journal ofPharmacy and Pharmaceutical Sciences. 2015;7(1).

40. Juliet. L, Karthik raja. S.R, Reena. V.L, Aarthi. V, Sathiya Rajeshwaran. Serankottai induced contact dermatitis during suthi process in Siddha -A case report. Journal of Pharmacovigilance and drug safety. $2019 ; 16(2)$. 